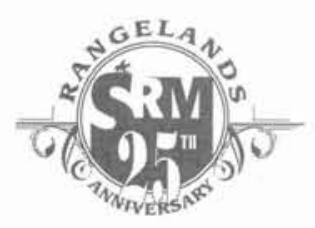

\title{
Range Plant Development In Utah: A Historical View
}

\section{A history of heavy grazing and semi-arid climate have given Utah a unique challenge in developing range plants suited to the West.}

\section{by R. Deane Harrison, N. Jerry Chatterton, E. Durant McArthur, Dan Ogle, Kay H. Asay, and Blair L. Waldron}

Editor's Note: We put the spotlight on Utah as SRM members gear up to attend the $57^{\text {th }}$ Annual Meeting of the Society for Range Management January 24-30, 2004 in Salt Lake City.

The native vegetation of Utah at the time of Mormon settlement in 1847 was not documented. However, early day species composition was indicated. Brigham Young received a letter two days before he entered Salt Lake Valley in 1847, from advance scouts, Orson Pratt, Willard Richards and George A. Smith stating that grass was plentiful and if they wanted to grow sagebrush they better bring seed (Cottam 1947). Cottam (1947) reviewed Orson Pratt's journal and found that on July 21, 1847 Pratt commented that the "very luxuriant" green grass cover extended for miles in the valley with bunch- grass growing on the upland valley plains. Government Explorer Howard Stansbury (1852) reported that the Salt Lake Valley afforded perennial pasturage and the hillsides furnished bunchgrass.

But, prolonged heavy livestock grazing, beginning shortly after Mormon pioneer settlement of Utah in 1847 , led to rangeland degradation. By the 1880 's and 1890's, livestock numbers peaked in Utah. The 1890 U.S. Agriculture Census recorded 3.8 million sheep and half a million cattle in the state (Fig. 1). This unsystematic and heavy grazing eventually led to vegetation community change.

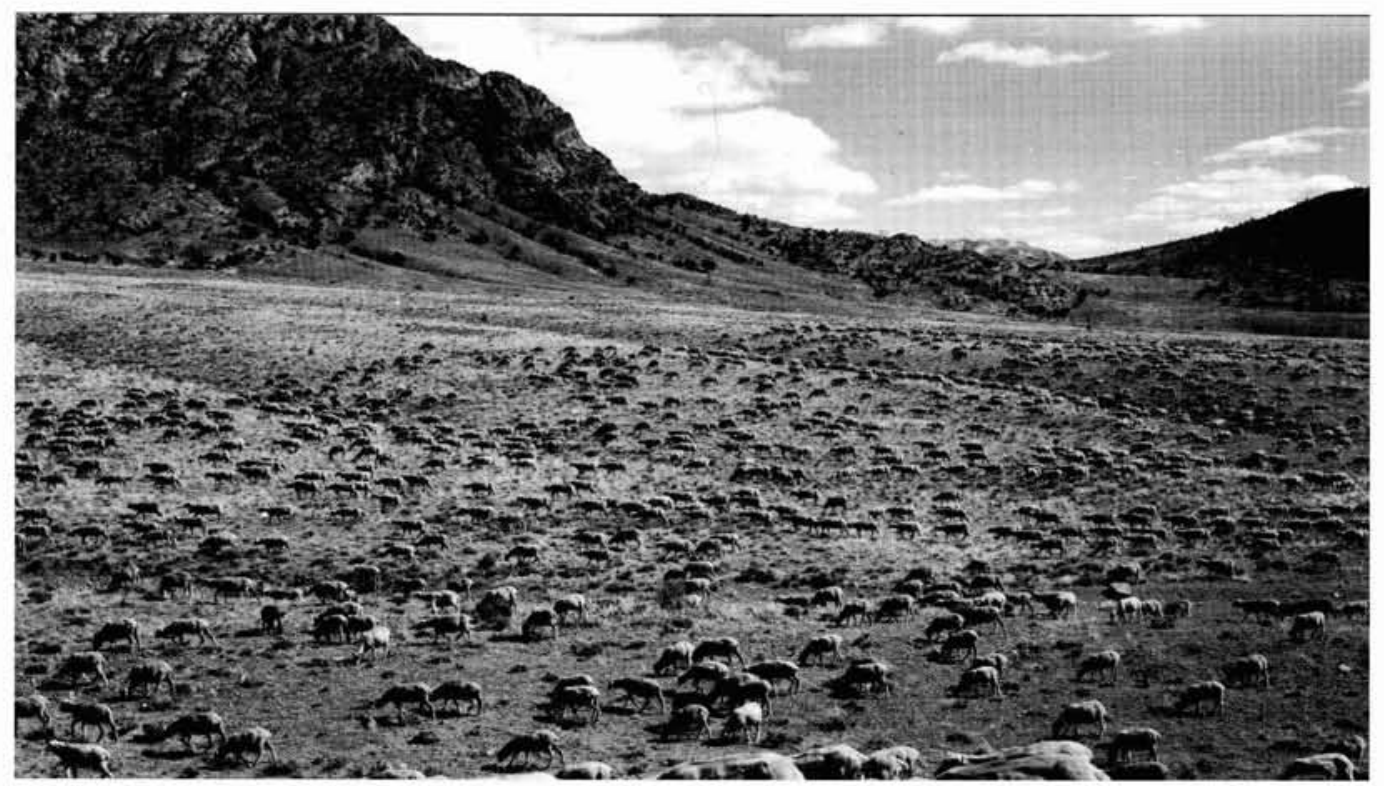

Figure 1. Sheep reached their peak in Utah at 3.8 million in the 1880's and 1890's. 
In 1932, Pickford reported that the vegetation on the Great Basin's eastern foothills had changed from $49-81 \%$ perennial grass and $10 \%$ sagebrush to mainly sagebrush ground cover. Soil surveys and correlated ecological range site descriptions completed in Utah by the United States Department of Agriculture, Natural Resources Conservation Service ([NRCS] formerly the Soil Conservation Service) support similar findings.

Passey et al. (1982) also reported similar findings in their classic studies conducted from 1958 through 1969 on several protected relict foothill areas. Hull and Hull (1974) reported that in Cache Valley Utah, perennial grasslands had changed to dense stands of sagebrush and cheatgrass. As a result of degraded ranges, catastrophic flooding occurred in the late 1800's and early 1900's in several Utah counties including Sanpete, Uinta, Duchesne, Davis, Emery, and Salt Lake. The city of Manti, in Sanpete County, was on the verge of being abandoned until livestock use was discontinued and a watershed program was developed for Manti Canyon.

Due to continued flooding, the USDA Forest Service (FS) created the Great Basin Experiment Station (now the Great Basin Experimental Range) in 1912 in Sanpete County and the Davis County Experimental Watershed in 1933.

Many ranchers, including the first author's grandfather, under the authority of the 1916 Stock-raising Homestead Act, continued to deplete the native vegetation, through grazing livestock too early and too heavily on homesteaded land and adjacent public lands. Rangelands continued to deteriorate, even though the Forest Reserve Policy was established in 1891 and management areas like Manti National Forest (approved in 1903) were created and the Taylor Grazing Act implemented in 1934.

In 1936, the U.S. Senate published the document, "The Western Range" which reported the serious condition of western rangelands.
Among other things, the report emphasized the need for seeding of grasses to stabilize the soil and improve the depleted range. Walter Cottam (1947) posed the question, "Is Utah Sahara Bound?" as he discussed the degraded state of rangeland in Utah and suggested the need for plant materials and reseeding to reclaim abused land.

\section{Plant Materials in Utah}

It is not clear whether Utah was included in the 1,500 Western Seeding Trials conducted by the Federal Government in 1895, which were largely failures; or in the 500 tests conducted in 11 western states by the Forest Service in 1907, which reported only $16 \%$ success (Chatterton and Young, 2002).

However, A. W. Sampson, who some consider the father of range management, established plots of various plant species at the Forest Service Great Basin Experiment Station in 1912 and 1913. During the autumn of 1912, he planted timothy, Kentucky bluegrass, orchardgrass, white sweetclover and red clover. In some cases sheep were herded over the seeded areas to trample in the seed (Fig. 2). In 1913, three thousand six hundred plant cuttings and sprouts of aspen, willow, mountain elder, and "other

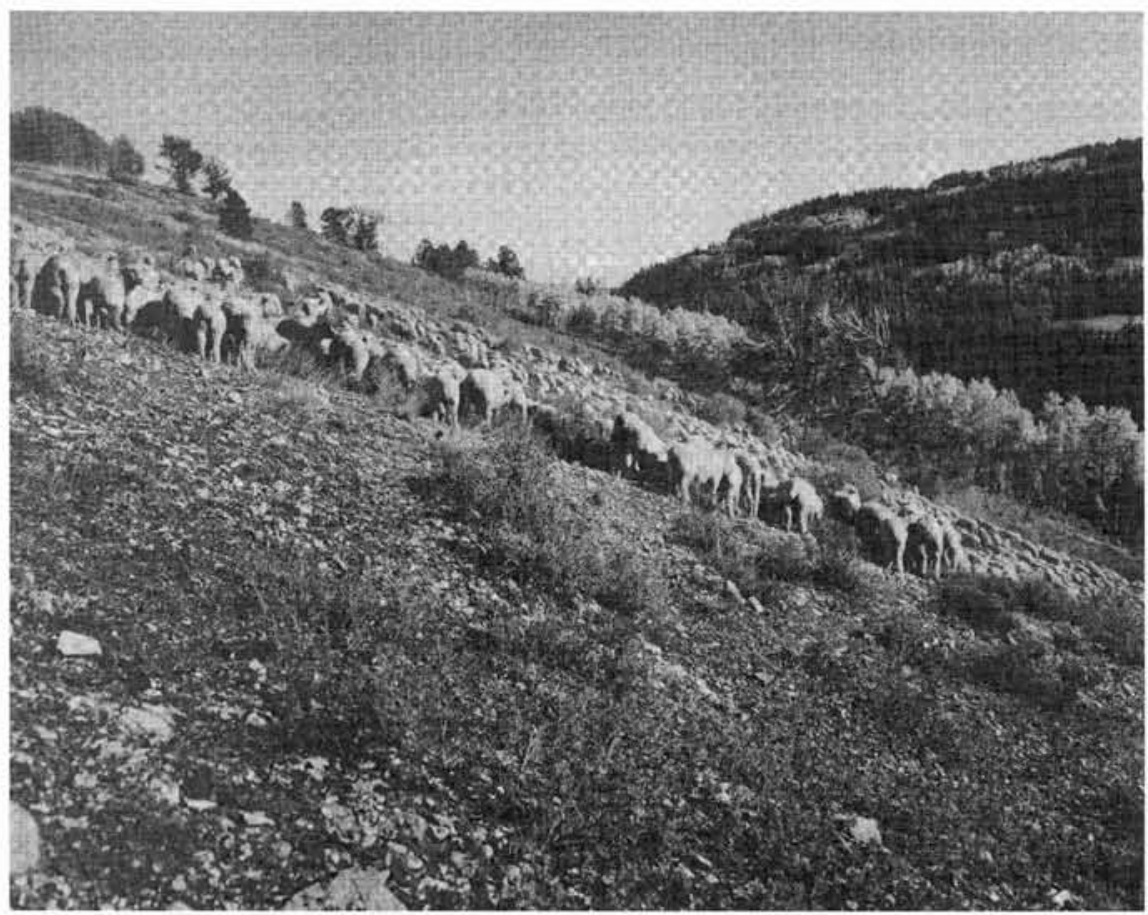

Figure 2. In the early 1900's, A.W. Sampson had sheep herded over broadcast seedings at the Great Basin Experiment Station, near Ephraim, UT. 


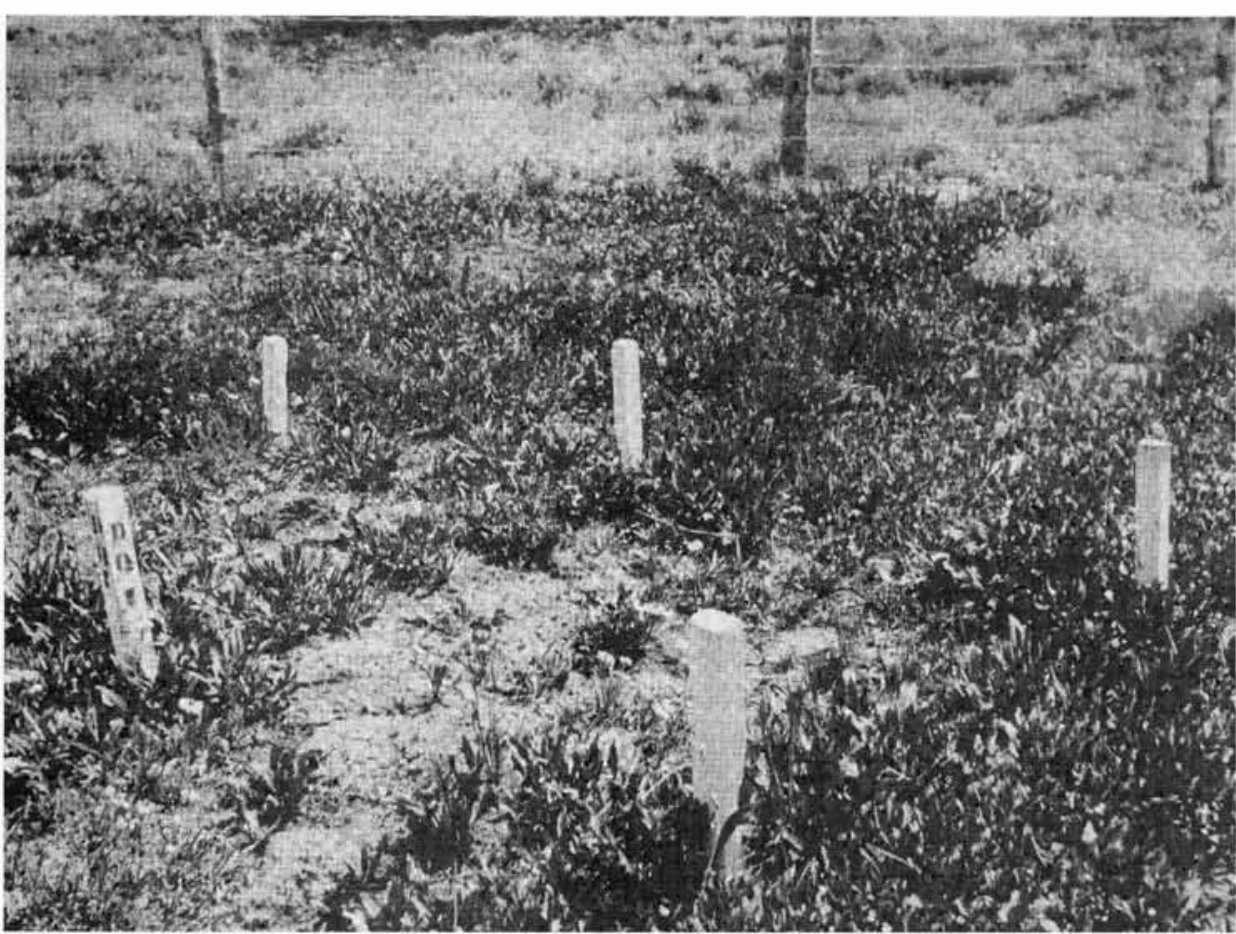

Figure 3. A.W. Sampson's 1913 plant material plots at Great Basin Experiment Station, near Ephraim, UT.

promising shrubs" were planted at the headwaters of mountain streams (Fig. 3) (Keck 1972). Willow was the only cutting that grew satisfactorily. Other grass species, including Idaho fescue, oniongrass, and bluebunch wheatgrass, were planted on a related project. At the end of 10 years, a report stated that satisfactory performance at the headwater sites, was obtained from penstemon, sweetsage, yarrow, slender wheatgrass, mountain brome, bottlebrush squirreltail, timothy, smooth brome and Kentucky bluegrass. Reseeding trials and plant selection efforts were greatly expanded in the Intermountain area when an organized testing program was developed by the USDA-FS in the 1920's.

In 1888, the Utah Agricultural Experiment Station (UAES), under the 1887 Hatch Act, was established at Logan, Utah. In 1903, 103 acres were acquired at Nephi, Utah for a new experiment station. This location is the oldest continuously operated dryland Experiment Station farm in the United States and has been the testing site for numerous rangeland plant materials.

The federal government purchased 3,240 acres of abandoned farmland in 1934 and established the Benmore Experimental Range for research (Astroth and Frischknecht 1984). In the fall of 1938 and the spring of 1939, the units were fenced, plowed, and seeded to a mixture of crested wheatgrass, smooth brome, slender wheatgrass, western wheatgrass, and tall oatgrass. Crested wheatgrass was the best adapted species and soon dominated $95 \%$ of the area. Those plantings represent some of the oldest crested wheatgrass seedings in the West. Later tall wheatgrass, intermediate wheatgrass and Russian wildrye were planted with some success. It was at the Benmore station that L.A. Stoddart and C.W. Cook from the UAES and N. C. Frischknecht of the Forest Service's research branch (then the Intermountain Forest and Range Experiment Station) did early plant material re-

search (Fig. 4).

Reseeding, along with contour trenching was accomplished at the Davis County Experimental Watershed (established in 1933). It is believed that the species used for reseeding were intermediate wheatgrass, smooth bromegrass, and yellow sweetclover, which were included in the standard USDAFS revegetation mountain seed mixture.

The USDA-FS Desert Experimental Range, at Utah's west desert, was established in 1933. The primary purpose of the Desert Experimental Range is to evaluate grazing intensities and season of grazing. However, adaptation of plant materials are also tested there. For example, fourwing saltbush has been planted around the headquarters buildings for adaptation and conservation evaluation.

The NRCS established several Soil Conservation Plant Nurseries (Plant Materials Center's [PMC]) in the 1930's. Utah is served by the PMCs in Aberdeen, Idaho (established in 1939); Los Lunas, New Mexico (established in 1937); Tucson, Arizona (established in 1935); and by the Upper Colorado Environmental Plant Center at Meeker, Colorado (established in 1975). 

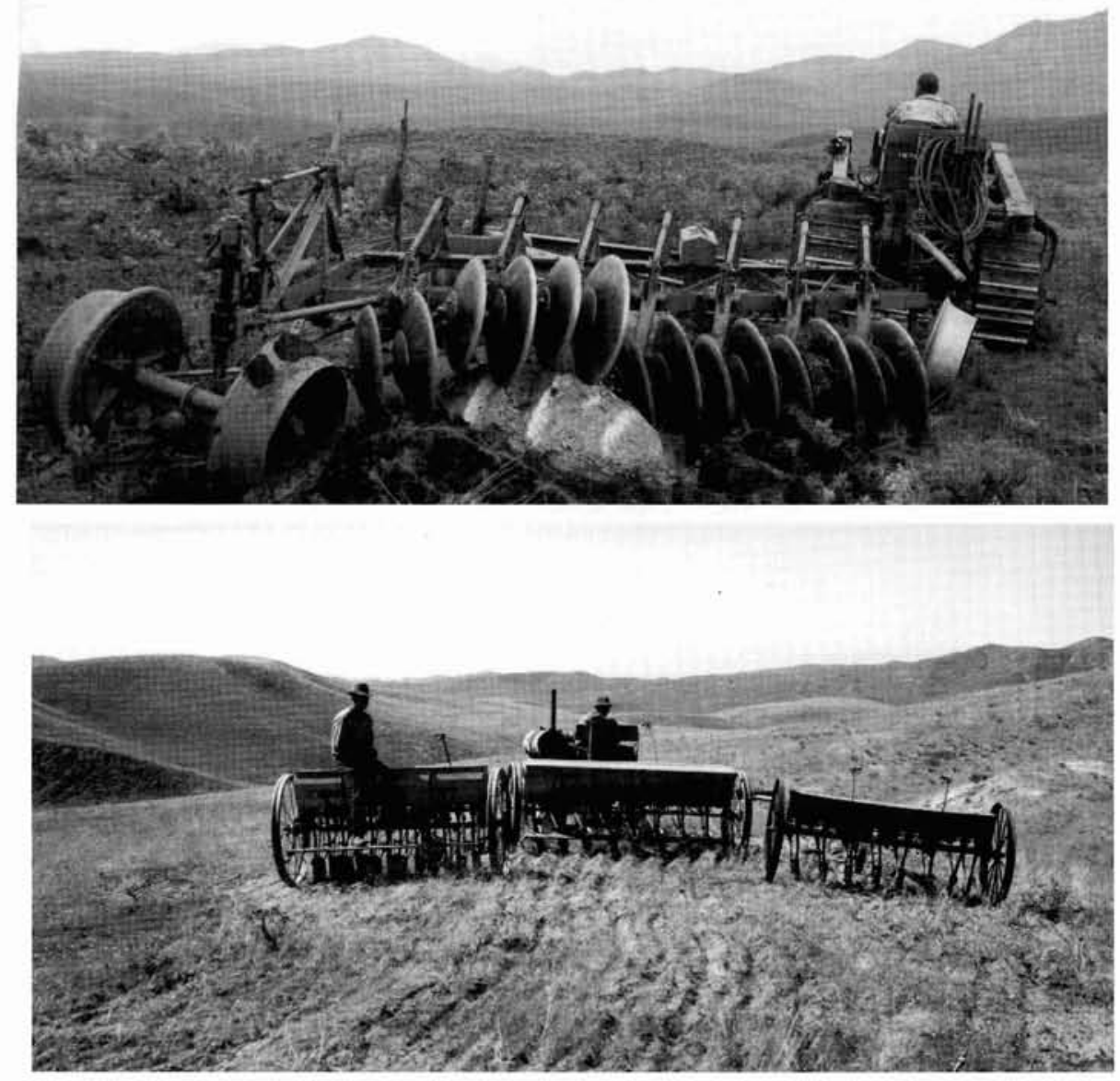

Figure 4. Thousands of degraded Utah rangelands were plowed and seeded to plant materials, as occurred at the Benmore Experiment Station.

Some of the early plant materials used in Utah that were released from PMCs include; 'Manchar' smooth brome-1943, 'Sherman' big bluegrass-1945, 'Greenar' intermediate wheatgrass-1945, 'Primar' slender wheatgrass-1946, 'Bromar' mountain brome-1946, 'Whitmar' bluebunch wheatgrass-1946, 'Ioreed' reed canarygrass-1946, 'Alkar' tall wheatgrass-1951, 'Topar' pubescent wheatgrass -1953 , 'P-27' Siberian wheatgrass-1953, 'Nordan' crested wheatgrass-1953, and 'Sodar' streambank wheatgrass-1954.

Additional plant materials used in Utah that have been released by PMC's in more recent years include 'Nezpar' and 'Rimrock" Indian ricegrass, 'Garrison' creeping foxtail, 'Regar' meadow brome, 'Secar' Snake River wheatgrass, 'Bannock' thickspike wheatgrass, 'Pryor' slender wheatgrass, 'Goldar bluebunch wheatgrass, 'Magnar' basin wildrye, 'Rosana' western wheatgrass, 'Luna' pubescent wheatgrass and many others.

In 1936, Wesley Keller was the first USDA Bureau of Plant Industry (BPI) employee hired under the cooperative program with the Agricultural College of Utah (Utah State University). In the 1940's, he joined with Bateman and Packer of the College to field test several pasture mixes that resulted in the "University Mix." In 1954, BPI became part of the United States Department of Agriculture, Agriculture Research Service (ARS) and many researchers were transferred to the new agency. The USDA-ARS, Forage and Range Research Laboratory in Logan, Utah has released twentyone cultivars and pre-variety germplasms. The Laboratory released seven alfalfa lines including 'Desert' during the 1970 's and early 1980's.

A few of the rangeland cultivars that were released in the 1980 's and 90's include: 'Newhy', RS-1, and RS-2 Hybrid wheatgrass; 'Hycrest', 'Douglas', and 'CDII' crested wheatgrass; 'Bozoisky - Select' and 'Tetra-1 tetraploid' Russian wildrye; 'Vavilov' Siberian wheatgrass; 'ARS-2678' kura clover; 'SL1 ' wheatgrass hybrid; 'Scarlet' and 'Munroe' globemallow; 'Timp' Utah sweetvetch; 'Sand Hollow' squirreltail grass; 'Rimrock' Indian ricegrass; 'Road Crest' turf-type crested wheatgrass; and P-7 bluebunch wheatgrass. Many of these were released jointly with other cooperators.

In 1975, the USDA-FS created the Shrub Sciences Laboratory as a unit in the Intermountain Forest and Range Experiment Station on the Brigham Young University campus in Provo, Utah. This laboratory was an outgrowth of previous plant ecology research and plant materials development from the Great Basin Station or Great Basin Experimental Range under a cooperative effort that included the 
Utah Division of Wildlife Resources big game habitat restoration unit. A. Perry Plummer led the combined efforts of the Laboratory for many years. In cooperation with other agencies, the Shrub Science Laboratory has made fifteen separate releases.

Some of the releases of the 1980's and early 1990's include 'Appar' blue flax, 'Rincon' fourwing saltbush, 'Ephraim' crested wheatgrass, 'Immigrant' forage kochia, 'Lassen' antelope bitterbrush, 'Hatch' winterfat, 'Paiute' orchardgrass, 'Hobble Creek' mountain big sagebrush, and 'Gordon Creek ' Wyoming big sagebrush. help build on each other's goals; acknowledge whom would take leadership for each plant species; designate a leader for seed increase; and enhance coordination of plant releases.

As a result of the discussion, the first Utah State Interagency Plant Materials Committee meeting was held in April 1985 and included both developers and users (Table 1). During the meeting the following areas were reviewed: 1) new research, seed availability of new plant releases, and adequate plot size; 2) user group needs; and 3) resource problems and priorities. It was agreed that before new plant

Table 1. Agencies Present at the 1985 Materials Correlation Meeting.

$\overline{\text { Agencies }}$

USDI-Bureau of Land Management

United States Department of Agriculture, Natural Resource Conservation Service (NRCS)

USDA-NRCS Plant Material Center Aberdeen, Idaho

Utah Division of Oil, Gas, and Mining

USDA Agricultural Research Service, Forage and Range Research Lab

Utah State University Extension

USDA Forest Service Intermountain Research Station Shrub Sciences Laboratory

USDA Forest Service Intermountain Region

Upper Colorado Environment Plant Center

Utah Division of Wildlife Resources

Utah Department of Agriculture, Division of Plant Industry

Utah Crop Improvement Association

Utah State Lands and Forestry

\section{Utah Interagency Plant Material Committee}

In 1985, NRCS was involved in developing a long range plant material plan for Utah and felt it necessary to receive input from other agencies that were developing and/or using plant materials. During discussions about the plan, R.D. Harrison, E.D. McArthur, K.H. Asay, N.J. Chatterton, F.T. Holt, J.C. Gibbs, and M.M. Petersen decided plant material development and use could benefit from interagency coordination by those that use plant materials and those that develop them.

The group felt that coordination would be useful to: minimize duplication of efforts; provide a forum to maximize plant material production; inform users of new species and varieties; reduce competition; materials were released the following should occur: 1) more evaluation and testing through a standard coordination procedure; 2 ) more demonstration plots and field plantings were needed; 3 ) seed should be available for purchase when plant materials are released; 4) better communication between the developer and user as to the value of the new plant; 5) seed quality testing for certification; and 6) a plant material priority list should be developed.

It was unanimously voted to form an interagency plant material coordination committee that would meet each year. The second annual meeting was held in March 1986 in Logan, Utah at which time a coordinated planting guide was discussed. Howard Horton, USDA-ARS, who had been working on a guide for range and pasture seeding was asked to chair a Planting Guide development committee. The 
Interagency Forage and Conservation Planting Guide for Utah was subsequently published in 1988 and was revised by USDA-ARS and others in 2001 as the Intermountain Planting Guide.

The Utah Interagency Plant Material Committee has evolved over the years as a forum to annually exchange information relating to plant materials development and use. It has been the inspiration for several states to initiate similar plant coordination forums and has expanded to include participants from Idaho and Nevada. A separate committee of scientists from agencies (USDA-ARS, USDANRCS, USDA-FS, and appropriate state agencies) that develop plant materials meet every two to three years and discuss many of the details as outlined in the original concepts discussed earlier in this paper.

\section{Looking Ahead}

Even though rangeland condition has improved in some areas, questions continue to be asked, "Is Utah Sahara bound"? Is desertification occurring in Utah? Are there needs for more and better plant materials? Bureau of Land Management officials state that fire and cheatgrass have created a weedy wasteland in The Great Basin and that a large part of it lies on the brink of ecological collapse. Sheldon Wimmer, Utah BLM Fire Management Officer stated, "In the early 1970's BLM Utah had an average of 25,000 to 30,000 acres of range fire per year. Now there is an average of 130,000 acres of cheatgrass related fires annually." The increasing trend of wildfire in Utah is also occurring in other Intermountain West States.

Steve A. Dewey, USU Extension Weed Specialist, reports that noxious weeds in Utah increase at a greater rate than the national average of 14 to $16 \%$ per year. Obviously, there is still a need for new and better plant materials. However, just as important is the need for plant materials coordination, better land management practices and the increased education of private users in range health and trend.

We refer to the initial purpose of the Utah Interagency Plant Material Committee: 1) minimize overlapping work; 2) provide a forum for cooperation; 3) reduce competition and establish who would take research leadership for each plant species; 4) designate leader for seed increase; 5) cooperate more fully on plant releases; and 6) provide information about new species and varieties for users and allow users to inform developers of their needs. The Utah Interagency Plant Materials Committee and its sister organizations continue to serve a useful role for land managers and plant developers.

About the Authors: Harrison is a range scientist, Utah State University, Logan, UT (emeritus USDA-NRCS); Chatterton is research physiologist and research leader, USDA Agricultural Research Service, Forage and Range Research Lab, Logan, UT; McArthur is project leader, USDA Forest Service, Shrub Sciences Laboratory, Provo, UT; Ogle is plant material specialist, USDA Natural Resources Conservation Service, Boise, ID; Asay is research geneticist (retired), USDA Agricultural Research Service, Forage and Range Research Lab, Logan, UT; and Waldron is research geneticist, USDA Agricultural Research Service, Forage and Range Research Lab, Logan, UT.

\section{References}

Astroth, K.A. and N.C. Frischknecht. 1984. Managing Intermountain Rangelands - Research on the Benmore Experimental Range, 1940-84. USDA-FS Gen. Tech. Report INT-175.

Chatterton, N.J. and J.A. Young. 2002. Grasses in the West: Early Days to the Present. Journal of the West. Vol. 41. No. 1, pp 25-35.

Cottam, W. P. 1947. Is Utah Sahara Bound? University of Utah Bul. No. 11 Vol 37.

Hull, A. C. and M. K. Hull. 1974. Presettlement Vegetation of Cache Valley, Utah and Idaho. Journal of Range Management 27 (1), pp 27-29.

Keck, W. M. 1972. Great Basin Station - Sixty Years of progress in Range and Watershed Research. USDA-FS Res. Paper INT-118.

Passey, H. B., V.K. Hugie, E. W. Williams and D. E. Ball. 1982. Relationships Between Soil, Plant Community, and Climate on Rangelands of the Intermountain West. SCS Technical Bulletin No. 1669. I123 p.

Pickford, G. D. 1932. The influence of continued heavy grazing and promiscuous burning on spring-fall ranges in Utah. Ecology 13:159-171.

Stansbury, Howard. 1852. Exploration and survey of the Valley of Great Salt Lake of Utah. Washington, D.C.

\section{Additional Reading}

Jensen, K.B., W.H. Horton, R. Reed, and R.E. Whitesides. 2001. Intermountain Planting Guide. 104 pp. Utah State University Extension Publication. AG510

Kitchen, S.G. and E.D. McArthur. 1996. Desert Experimental Range. USDA-FS Gen. Tech. Report INTGTR-334. pp 15-2I. 
McArthur, E.D. and S.B. Monsen. 1996. Great Basin Experimental Range. USDA-FS Gen. Tech Report INTGTR-334. pp 23-30.

McArthur, E.D. 2001. The Shrub Sciences Laboratory at 25 years: Retrospective and Prospective. In McArthur, E.D. and D.J. Fairbank (comps.), Shrubland Ecosystem Genetics and Biodiversity: RMRS-P-21 USDA-FS Rocky Mountain Research Station Ogden, Utah. pp 3-41.

Monsen, S.B. and E.D. McArthur. 1993. Implications of Early Intermountain Range and Watershed Restoration Practices. USDA-FS Gen. Tech. INT-GTR-315. pp 16-25.
Monsen, S.B. and N.L. Shaw. 2001. Development and Use of Plant Resources for Western Wildlands. In McArthur, E.D. and D.J. Fairbank (comps.), Shrubland Ecosystem Genetics and Biodiversity: RMRS-P-21 USDA-FS Rocky Mountain Research Station, Ogden, Utah. pp 47-61.

Pratt, Orson. 1849-1850. Orson Pratt's Jour. Mill. Star, Vol. $11-12$.

USDA-NRC. 2001. National Plant Materials Program http://Plant-Materials.nrcs.usda.gov

Stoddart, L.A. and A. D. Smith. 1955. Range Management. McGraw-Hill Book Co. Inc. 433 p.

\section{Showing the Way}

CRP Grasses

- Sharpshooter

Burfalograss

- Native and

Introduced

Grasses

-Custom Seed

Mixes

- Turf Crasses

- Reclamation

Grasses

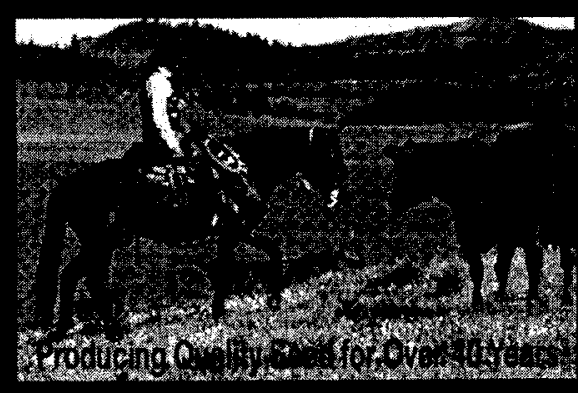

Wildlife Mixes

- Field Seeds

-Certified Wheat

- Hybrid Forage

Sorghum

-Sorghum

Sudangrass

Hybrids

-Mulit-Leaf

Alfalfa

- Wildflowers

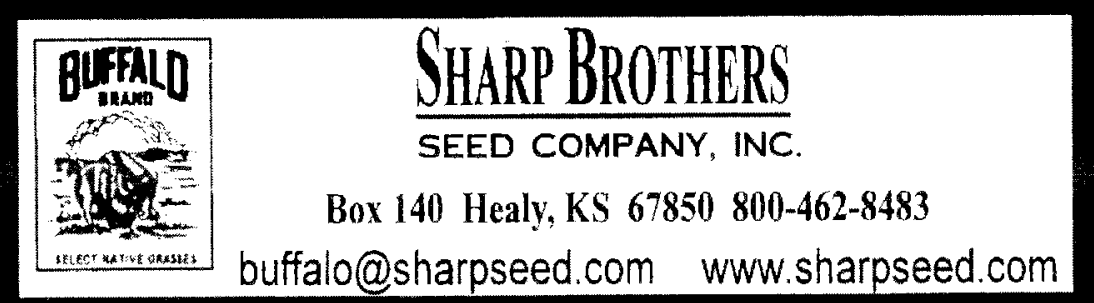

